\title{
Corporate Governance at the World Bank and the Dilemma of Global Governance
}

\author{
Ashwin Kaja and Eric Werker
}

\begin{abstract}
Most major decisions at the World Bank are made by its Board of Executive Directors. While some countries enjoy the opportunity to serve on this powerful body, most countries rarely, if ever, get that chance. This gives rise to the question: Does board membership lead to higher funding from the World Bank's two main development financing institutions, the International Bank for Reconstruction and Development (IBRD) and the International Development Association (IDA). Empirical analysis shows that developing countries serving on the board can expect more than double the funding from the IBRD as countries not on the board. In absolute terms, countries on the board receive an average $\$ 60$ million "bonus" in IBRD loans, an amount that rises in years when IBRD loans are in high demand, particularly for countries in the most influential seats. This effect is more likely driven by informal rules and norms in the boardroom than by the power of the vote itself. No significant effect is found in IDA funding. These results point to challenges of global governance through representative institutions. JEL codes: F34, F35, F53, G34
\end{abstract}

Understanding that real-time decisions on global governance cannot be made by a consensus of all countries, founders of international institutions often grant decisionmaking powers to a smaller, nimbler body. But country representatives on these bodies face an inevitable tension between promoting their national interests and those of the larger international community.

A similar dilemma arises in U.S. politics and business. Since the seminal work of Ferejohn (1974), scholars have found that membership on powerful committees allows members of Congress to bring home the pork to their local

Ashwin Kaja (kaja@post.harvard.edu.) is a juris doctor candidate at Harvard Law School. Eric Werker (corresponding author, ewerker@hbs.edu) is associate professor at Harvard Business School. The authors thank Tiffany Chan, Axel Dreher, Jeff Frieden, Arif Lakhani, Tracy Li, Linda Liu, Kenneth Mirkin, James Vreeland, Matthew Young, and seminar participants at the Political Economy of International Organizations, the International Political Economy Society meetings, and the World Bank for insightful conversations and feedback; Byron Hussie, Michael Sorell, and James Zeitler for excellent research assistance; and the journal editor and three anonymous referees for useful comments and suggestions. Werker acknowledges financial support from the Harvard Business School Division of Research and Faculty Development. A supplemental appendix to this article is available at http://wber. oxfordjournals.org/.

THE WORLD BANK ECONOMIC REVIEW, VOL. 24, NO. 2, pp. 171-198

doi:10.1093/wber/lhq006

Advance Access Publication June 14, 2010

(C) The Author 2010. Published by Oxford University Press on behalf of the International Bank for Reconstruction and Development / THE WORLD BANK. All rights reserved. For permissions, please e-mail: journals.permissions@oxfordjournals.org 
constituencies (Ray 1981; Rundquist, Lee, and Rhee 1996; Carsey and Rundquist 1999; Rundquist and Carsey 2002). A parallel, though surprisingly thin, literature on corporate finance and law examines how corporate board members benefit from their positions at the expense of the larger company (Bebchuk and Fried 2004; Brick, Palmon, and Wald 2006).

Countries-unlike states in Congress-do not have equal access to the most powerful international bodies, such as the Group of Seven industrial countries, the Group of 20 developed and developing countries, and the U.N. Security Council. This article investigates the consequences of unequal access to decisionmaking at the international level, looking at the politics of corporate governance in the world's largest appropriations committee, the World Bank's Board of Executive Directors.

In 2008, the World Bank's two primary component institutions-the International Bank for Reconstruction and Development (IBRD) and the International Development Association (IDA)—committed nearly \$25 billion in loans and grants through more than 300 development projects around the globe. The IBRD offers low-interest loans to middle- and low-income developing countries. The IDA focuses exclusively on loans and grants to the world's poorest and neediest countries. Each institution is overseen by a Board of Executive Directors, composed of representatives of shareholding countries, which approves all projects and policies. The 5 largest shareholding countries appoint 5 of the 24 country members of the board, while the remaining 19 are elected for renewable two-year terms. The elected members typically vote on behalf of a handful of other countries. Thus, the vast majority of member states find their interests represented by another country.

The article tests whether members of the board bring more Bank funds to their home countries. It finds a strong effect for the IBRD. Yet a simple correlation may not be particularly illuminating. After all, a country with board membership may be overseeing Bank loans granted previously. Or a board seat may reflect a country's rise in international prestige, which could independently bring about more World Bank projects. If true, these explanations may not be entirely troubling. The article argues, however, that the data are better explained by self-serving behavior in which membership on the board is used as a platform to channel more or larger Bank loans and grants to the directors' home countries. The analysis does not rule out the possibility that World Bank staff prefer to lend to countries with a seat on the board, but the distributional implications are the same.

The results are stark: countries receive a large increase in IBRD loans during years when they have a seat on the board. Specifically, developing countries serving on the Board of Executive Directors can expect more than a doubling of funds on average from the IBRD. Countries serving on the board are rewarded with an average \$60 million "bonus" in IBRD loans. Only the time on the board, not the years before or after, is associated with increased commitments. Developing countries representing seats with a higher "effective 
vote"-seats shared by richer countries that are themselves uninterested in IBRD loans-tend to get larger increases. Moreover, countries with directors on the board receive the largest increases during years in which IBRD funding is in greatest demand-when the value of a seat is the highest.

The data do not yield the same results for IDA funding: no significant association is found between board membership and IDA loan and grant commitments. The difference in IBRD and IDA results may be explained by differences in their missions and funding policies. The IDA has allocated funding using a performance- and poverty-based formula since 1977 (IDA 2004), while GDP per capita and regional equity have been of central concern since the organization's early years (Kapur, Lewis, and Webb 1997).

While the findings for the IBRD are extremely robust, there are hints that executive board power may come largely from having a seat at the table rather than from the mathematical allotment of voting power itself. Alternate board members-who are entitled to vote only when their executive director is absent-receive similar increases in commitments. (It turns out that executive directors are absent quite frequently.) With this lack of distinction, it may be that the informal workings of the IBRD Board of Executive Directors or the informal networks between Bank staff and board members/alternates reward insiders without distinguishing greatly between them.

The article is organized as follows. Section I describes the World Bank's decisionmaking structures, particularly the Board of Executive Directors. Section II introduces the data and explains the empirical methodology underlying the analysis. Section III presents the results, while section IV examines whether the IBRD bonus varies by other factors. Section V offers some concluding remarks.

\section{Decisionmaking at the World Bank}

The World Bank has 186 members. ${ }^{1}$ Its two main branches, the IBRD and the IDA, perform different functions that contribute to its broader mission. The IBRD, the historical core of the Bank's operations, now directs credit mainly to middle-income and creditworthy poorer countries (World Bank 2007). Loans finance specific projects and programs. An undisclosed methodology determines the amount of IBRD loans that can be made to a country. Most countries are well below this lending ceiling. The scarcity of loans is assured by the limited staff capacity to evaluate project viability and structure loans. The IDA focuses on the world's neediest countries-countries that fall below a certain income threshold, have poor credit ratings, or in some other way require special assistance. The IDA is more responsive to short-term disasters and emergencies and has the power to negotiate the income ceiling under

1. Unless otherwise cited, everything in this section is drawn from the World Bank's Articles of Agreement (World Bank 2007) or its current website (www.worldbank.org). 
special circumstances, although a strong norm for allocative guidelines has been around since at least 1964 (Kapur, Lewis, and Webb 1997). Since 1977, an explicit formula, the Performance-Based Allocation System, has been the basis for distributing IDA funds (IDA 2004).

\section{Membership and Voting Power}

The World Bank is structured like many major corporations and banks. However, it is solely owned by countries, which serve as its shareholders. The IBRD currently has 186 shareholding member countries while the IDA has 169 (most countries are "blend" countries, belonging to both groups). Each member country is required to purchase a certain number of shares based on a formula that accounts for its weight in the world economy (Woods 2001). The shareholders are technically the ultimate authority in Bank decisions. Each country is assigned a certain number of votes in broad, high-level Bank decisionmaking that is related to the number of shares it owns. These votes are an explicit valuation of a country's power within the institution. The Articles of Agreement allocate 250 basic votes to each country plus one additional vote for each share of stock held. While the 250 basic votes are a concession to the principle of equality, tremendous growth in the total number of shares has marginalized their value. At the peak in 1955, the basic votes accounted for 14 percent of votes at the Bank; by 2001, they accounted for just 3 percent (Woods 2001).

\section{Decisionmaking and Election of Executive Directors}

Each World Bank member country appoints a governor and an alternate governor to serve a five-year term on the IBRD's Board of Governors. Usually, finance ministers or ministers of development are chosen as governors. If the country is also a member of the IDA, the governor serves ex officio on the IDA Board of Governors as well. While officially the highest authority at the Bank, the Board of Governors meets only once a year. Governors "admit or suspend members, increase or decrease the authorized capital stock, determine the distribution of net income, review financial statements and budgets, and exercise other powers that they have not delegated to the Executive Directors" (World Bank 2010).

The Board of Governors delegates all powers not expressly reserved for the governors in the Articles of Agreement to the Board of Executive Directors. Thus, the Board of Executive Directors is responsible for the general operations of the Bank and makes important day-to-day decisions. The board meets regularly and is responsible for approving Bank loan and grant proposals put forth by management. Executive directors report to the Board of Governors on Bank operations, accounts, and other matters during the Bank's annual meetings.

Because having a board that includes all member countries would be unwieldy, the Articles of Agreement establish a procedure for having multiple 
countries represented by one executive director. Executive directors are generally elected every two years at the Bank's annual meetings. Each member country casts all the votes allotted to that country for a single candidate. Additional election rules, which must be adopted by the Board of Governors before each election, customarily help ensure geographic diversity. As with governors, each IBRD executive director whose country is also a member of the IDA serves as an ex officio member of the IDA Board of Executive Directors.

In the conduct of regular business, executive directors cast votes, as a unit, for all the countries that they represent. Executive directors may appoint an alternate to assume full power and responsibilities in their absence. When executive directors are present at meetings, alternates may participate but cannot vote. In general, matters before the board are decided by majority vote.

It is this decisionmaking structure that motivates the empirical analysis. At any given time, most countries do not serve on the Board of Executive Directors, making executive directors responsible for representing the varied interests of the Bank's diverse membership in important decisions. Since executive directors are expected to represent the interests of the whole, they are not to use their temporary influence to further their own countries' agendas. Moreover, since many countries rarely or never serve on the board (tables 1 and 2), providing higher Bank funding for the countries that do would clearly be an unfair advantage.

The seats are quite heterogeneous. Currently, eight seats are occupied by individual countries: China, France, Germany, Japan, Russia, Saudi Arabia, the United Kingdom, and the United States. Most of the others are shared by developed and developing countries-for example, Canada and Ireland share a seat with a handful of Caribbean countries, and Australia and New Zealand share with a number of Oceanic and Southeast Asian countries. Some seats represent exclusively developing countries-for example, Sub-Saharan African countries have two seats. These groupings have changed over time: India once had its own seat, for example, while Saudi Arabia was once grouped with other predominantly Muslim countries. A seat may rotate among members, or a single developed country or regional hegemon may retain the directorship. Nearly all developing countries that have served as board members (and most that have not) have received funding from the World Bank. A handful of poor countries that have served on the board have received only IDA funding. Namibia is the only developing country in the sample that has served on the board but has received no World Bank funding.

While there are no published analyses of the inner workings of the Board of Executive Directors, ${ }^{2}$ the authors were able to speak in confidence with former directors. Their descriptions suggest that each seat on the board is run differently, with a different process for selecting directors and alternates, when there 
TABLE 1. Years of Service on the International Bank for Reconstruction and Development Executive Board of Directors, by Country, 1947-2005

\begin{tabular}{|c|c|c|c|c|c|c|c|}
\hline Country & Years & Country & Years & Country & Years & Country & Years \\
\hline Afghanistan & 0 & Dominica & 0 & Luxembourg & 0 & Singapore & 0 \\
\hline Albania & 0 & Dominican Republic & 0 & Macedonia, FYR & 0 & Slovak Republic & 0 \\
\hline Algeria & 22 & Ecuador & 2 & Madagascar & 7 & Slovenia & 0 \\
\hline Angola & 0 & Egypt, Arab Rep. & 7 & Malawi & 4 & Solomon Islands & 0 \\
\hline Antigua and Barbuda & 0 & El Salvador & 3 & Malaya & 2 & Somalia & 0 \\
\hline Argentina & 23 & Equatorial Guinea & 0 & Malaysia & 15 & South Africa & 0 \\
\hline Armenia & 0 & Eritrea & 2 & Maldives & 0 & Spain & 19 \\
\hline Australia & 37 & Estonia & 0 & Mali & 4 & Sri Lanka & 0 \\
\hline Austria & 8 & Ethiopia & 4 & Malta & 0 & St. Kitts and Nevis & 0 \\
\hline Azerbaijan & 0 & Fiji & 0 & Marshall Islands & 0 & St. Lucia & 0 \\
\hline Bahamas & 0 & Finland & 9 & Mauritania & 10 & St. Vincent \& the Grenadines & 0 \\
\hline Bahrain & 0 & France & 57 & Mauritius & 0 & Sudan & 3 \\
\hline Bangladesh & 0 & Gabon & 1 & Mexico & 10 & Suriname & 0 \\
\hline Barbados & 0 & Gambia, The & 2 & Micronesia, Fed. Sts. & 0 & Swaziland & 0 \\
\hline Belarus & 0 & Georgia & 0 & Moldova & 0 & Sweden & 12 \\
\hline Belgium & 50 & Germany & 51 & Mongolia & 0 & Switzerland & 13 \\
\hline Benin & 3 & Greece & 2 & Morocco & 12 & Tajikistan & 0 \\
\hline Bhutan & 0 & Grenada & 0 & Mozambique & 2 & Tanzania & 2 \\
\hline Bolivia & 6 & Guatemala & 0 & Myanmar & 0 & Thailand & 14 \\
\hline Bosnia and Herzegovina & 0 & Guinea & 0 & Namibia & 2 & Timor-Leste & 0 \\
\hline Botswana & 2 & Guinea-Bissau & 3 & Nepal & 0 & Togo & 0 \\
\hline Brazil & 11 & Guyana & 0 & Netherlands & 55 & Tonga & 0 \\
\hline Brunei Darussalam & 0 & Haiti & 0 & New Zealand & 15 & Trinidad and Tobago & 0 \\
\hline
\end{tabular}




\begin{tabular}{|c|c|c|c|c|c|c|c|}
\hline Bulgaria & 0 & Honduras & 0 & Nicaragua & 2 & Tunisia & 4 \\
\hline Burkina Faso/Upper Volta & 0 & Hungary & 0 & Niger & 0 & Turkey & 6 \\
\hline Burundi & 5 & Iceland & 11 & Nigeria & 5 & Turkmenistan & 0 \\
\hline Cambodia & 0 & India & 58 & Norway & 8 & Uganda & 2 \\
\hline Cameroon & 0 & Indonesia & 8 & Oman & 0 & Ukraine & 0 \\
\hline Canada & 58 & Iran, Islamic Rep. & 0 & Pakistan & 29 & United Arab Emirates & 0 \\
\hline Cape Verde & 0 & Iraq & 0 & Palau & 0 & United Kingdom & 58 \\
\hline Central African Republic & 4 & Ireland & 0 & Panama & 2 & United States & 58 \\
\hline Chad & 0 & Israel & 0 & Papua New Guinea & 0 & Uruguay & 7 \\
\hline China & 50 & Jamaica & 0 & Peru & 5 & Vanuatu & 0 \\
\hline Colombia & 33 & Japan & 51 & Philippines & 8 & Venezuela & 12 \\
\hline Comoros & 4 & Jordan & 0 & Poland & 3 & Vietnam & 0 \\
\hline Congo, Dem. Rep. & 0 & Kazakhstan & 0 & Portugal & 0 & Yemen & 0 \\
\hline Congo, Rep. & 4 & Kenya & 0 & Qatar & 0 & Yemen, Rep. & 0 \\
\hline Costa Rica & 1 & Kiribati & 0 & Romania & 0 & Yugoslavia & 0 \\
\hline Côte d'Ivoire & 0 & Korea, Rep. & 5 & Russian Federation & 13 & Zambia & 0 \\
\hline Croatia & 0 & Kuwait & 20 & Rwanda & 0 & Zimbabwe & 0 \\
\hline Cyprus & 0 & Lao PDR & 0 & San Marino & 0 & & \\
\hline Czech Republic & 0 & Latvia & 0 & São Tomé and Príncipe & 0 & & \\
\hline Czechoslovakia & 0 & Lebanon & 0 & Saudi Arabia & 19 & & \\
\hline Dahomey & 0 & Lesotho & 1 & Senegal & 0 & & \\
\hline Denmark & 11 & Liberia & 3 & Serbia & 0 & & \\
\hline \multirow[t]{2}{*}{ Djibouti } & 0 & Libya & 0 & Seychelles & 0 & & \\
\hline & & Lithuania & 0 & Sierra Leone & 2 & & \\
\hline
\end{tabular}

Source: Authors' analysis based on data described in the text. 
Table 2. Years of Service on the International Development Association Board of Executive Directors, by Country, $1961-2005$

\begin{tabular}{|c|c|c|c|c|c|c|c|}
\hline Country & Years & Country & Years & Country & Years & Country & Years \\
\hline Afghanistan & 0 & Dominica & 0 & Luxembourg & 0 & Singapore & 0 \\
\hline Albania & 0 & Dominican Republic & 0 & Macedonia, FYR & 0 & Slovak Republic & 0 \\
\hline Algeria & 22 & Ecuador & 0 & Madagascar & 7 & Slovenia & 0 \\
\hline Angola & 0 & Egypt, Arab Rep. & 7 & Malawi & 4 & Solomon Islands & 0 \\
\hline Antigua and Barbuda & 0 & El Salvador & 3 & Malaya & 0 & Somalia & 0 \\
\hline Argentina & 21 & Equatorial Guinea & 0 & Malaysia & 15 & South Africa & 0 \\
\hline Armenia & 0 & Eritrea & 2 & Maldives & 0 & Spain & 17 \\
\hline Austria & 8 & Ethiopia & 4 & Malta & 0 & St. Kitts And Nevis & 0 \\
\hline Azerbaijan & 0 & Fiji & 0 & Marshall Islands & 0 & St. Lucia & 0 \\
\hline Bahamas & 0 & Finland & 9 & Mauritania & 10 & St. Vincent \& the Grenadines & 0 \\
\hline Bahrain & 0 & France & 44 & Mauritius & 0 & Sudan & 2 \\
\hline Bangladesh & 0 & Gabon & 1 & Mexico & 10 & Suriname & 0 \\
\hline Barbados & 0 & Gambia, The & 2 & Micronesia, Fed. Sts. & 0 & Swaziland & 0 \\
\hline Belarus & 0 & Georgia & 0 & Moldova & 0 & Sweden & 9 \\
\hline Belgium & 36 & Germany & 44 & Mongolia & 0 & Switzerland & 13 \\
\hline Benin & 3 & Greece & 0 & Morocco & 12 & Tajikistan & 0 \\
\hline Bhutan & 0 & Grenada & 0 & Mozambique & 2 & Tanzania & 2 \\
\hline Bolivia & 6 & Guatemala & 0 & Myanmar & 0 & Thailand & 14 \\
\hline Bosnia and Herzegovina & 0 & Guinea & 0 & Namibia & 2 & Timor-Leste & 0 \\
\hline Botswana & 2 & Guinea-Bissau & 3 & Nepal & 0 & Togo & 0 \\
\hline Brazil & 11 & Guyana & 0 & Netherlands & 44 & Tonga & 0 \\
\hline Brunei Darussalam & 0 & Haiti & 0 & New Zealand & 15 & Trinidad and Tobago & 0 \\
\hline
\end{tabular}




\begin{tabular}{|c|c|c|c|c|c|c|c|}
\hline Bulgaria & 0 & Honduras & 0 & Nicaragua & 0 & Tunisia & 4 \\
\hline Burkina Faso/Upper Volta & 0 & Hungary & 0 & Niger & 0 & Turkey & 0 \\
\hline Burundi & 5 & Iceland & 10 & Nigeria & 5 & Turkmenistan & 0 \\
\hline Cambodia & 0 & India & 45 & Norway & 6 & Uganda & 2 \\
\hline Cameroon & 0 & Indonesia & 5 & Oman & 0 & Ukraine & 0 \\
\hline Canada & 45 & Iran, Islamic Rep. & 0 & Pakistan & 20 & United Arab Emirates & 0 \\
\hline Cape Verde & 0 & Iraq & 0 & Palau & 0 & United Kingdom & 44 \\
\hline Central African Republic & 4 & Ireland & 0 & Panama & 0 & United States & 44 \\
\hline Chad & 0 & Israel & 0 & Papua New Guinea & 0 & Uruguay & 7 \\
\hline China & 37 & Jamaica & 0 & Peru & 3 & Vanuatu & 0 \\
\hline Colombia & 26 & Japan & 43 & Philippines & 8 & Venezuela & 12 \\
\hline Comoros & 4 & Jordan & 0 & Poland & 0 & Vietnam & 0 \\
\hline Congo, Dem. Rep. & 0 & Kazakhstan & 0 & Portugal & 0 & Yemen & 0 \\
\hline Congo, Rep. & 4 & Kenya & 0 & Qatar & 0 & Yemen, Rep. & 0 \\
\hline Costa Rica & 1 & Kiribati & 0 & Romania & 0 & Yugoslavia & 0 \\
\hline Côte d'Ivoire & 0 & Korea, Rep. & 5 & Russian Federation & 13 & Zambia & 0 \\
\hline Croatia & 0 & Kuwait & 20 & Rwanda & 0 & Zimbabwe & 0 \\
\hline Cyprus & 0 & Lao PDR & 0 & San Marino & 0 & & \\
\hline Czech Republic & 0 & Latvia & 0 & São Tomé and Príncipe & 0 & & \\
\hline Czechoslovakia & 0 & Lebanon & 0 & Saudi Arabia & 19 & & \\
\hline Dahomey & 0 & Lesotho & 1 & Senegal & 0 & & \\
\hline Denmark & 9 & Liberia & 3 & Serbia & 0 & & \\
\hline \multirow[t]{2}{*}{ Djibouti } & 0 & Libya & 0 & Seychelles & 0 & & \\
\hline & & Lithuania & 0 & Sierra Leone & 2 & & \\
\hline
\end{tabular}

Source: Authors' analysis based on data described in the text. 
is any rotation at all. In board meetings, loan requests are almost always granted, and according to these sources, a norm exists that restrains directors from developing countries from voting against each other's requests. However, before meetings, the directors-most of them politically important figures from their home countries-often have a chance to make their views known on potential projects. Bank staff, meanwhile, are aware of the board status of the countries to which they are lending.

\section{Data And Methodology}

The empirical strategy for determining whether countries serving on the World Bank's Board of Executive Directors are able to use this position of influence to bring more Bank funding to their countries is to observe how approval of World Bank loan commitments varies as a function of having a seat on the board or not. A simple correlation between board membership and loan commitments is not, in itself, necessarily illuminating. Factors that affect a country's likelihood of serving on the Board of Executive Directors and its likelihood of receiving World Bank funding could bias this result. The methods described here provide empirical support for the hypothesis that board membership itself, rather than alternative explanations, drives the positive association between Bank funding commitments and board membership-the pork-barrel hypothesis.

A panel dataset was constructed featuring Part II IDA countries (mainly low- and middle-income countries) that have been members of the World Bank at any time since its founding. The main dependent variables are approved loan commitments from the IBRD and approved loan and grant commitments from the IDA. Data on all World Bank development projects since 1946 are readily available on its website, but the sample is restricted to projects after 1961, when the Part-II IDA definition first came into use. Funding commitments for each country in a given year are summed and converted to 1996 dollar values. ${ }^{3}$ In analyzing the characteristics of World Bank lending, this article is in the tradition of Andersen, Hansen, and Markussen (2006) and Kilby (2009).

The World Bank's annual reports contain a wealth of information, if not in a readily usable format (World Bank various years). The information is used to construct three key variables. The first is a dummy variable (Board member) representing whether a country served on the Board of Executive Directors in a given year. The number of times each country in the dataset served on the IBRD and the IDA boards is shown in tables 1 and 2. Around half the

3. Since the project database contains only approved loan commitments, countries eligible but not receiving funding are omitted. So that these country-years are included in the dataset, they are assigned a value of zero. In specifications using the logarithm of Bank commitments as the dependent variable, these values are set to a negligible $\$ 1$ (since $\ln (1)=0)$. 
countries that were members of the World Bank at some point since its founding have never served on the board-countries from Afghanistan and Albania to Zambia and Zimbabwe. Other countries, including Colombia, India, and Pakistan, have served many times. Because terms on the board begin and end in the middle of the calendar year while all other data are on a calendar year basis, the half-year lag effect must be accounted for when interpreting the results of the analysis. A similar variable reflects the same information for alternate directors (Alternate board). Summary statistics (reported in table S1 in the supplemental appendix, available at http://wber.oxfordjournals.org) are shown in table 3 for full board members, alternate board members, and other countries.

A second variable indicates the amount of voting power assigned to each Bank member country based on its number of World Bank shares (Bank voting power). The amount of voting power may indicate a country's pull within the institution. A third variable, drawn from data in the annual reports, reflects the aggregate voting power each board member wields in making board decisions (Board voting power). It is calculated by dividing each executive director's votes (equal to the sum of the general Bank votes of each country that executive director represents) by the total votes available that year. While Board member is a dummy variable that identifies whether a country is serving on the board in a given year, this scalar variable takes into account the fact that all board seats are not created equal by scaling membership by each seat's aggregate voting power. Board voting power for developing countries on the IBRD board, for instance, varies from less than 1.6 percent (Comoros in 1995) to nearly 6 percent (India in 1982).

The pork-barrel hypothesis is tested using two types of specifications. The main model is a fixed effects regression, and the second is an event-time specification that continues to use fixed effects but analyzes trends before and after membership. Robustness checks and additional tests show whether some types of board members are systematically more effective in bringing home additional aid. The main specifications use the logarithm of World Bank funding commitments as the dependent variable, while alternate specifications also use absolute levels of commitments and a logit model. Additionally, loan receipts are compared for countries represented by executive directors and those represented by alternate directors to examine whether the vote itself or a more complex institutional factor explains increased loans. All specifications include standard errors clustered at the country level.

In addition to the Bank voting power variable described above, the analysis controls for several other factors. Data from the Penn World Tables (Heston, Summers, and Aten 2009) are used to control for the log of real per capita GDP and population-both factors that might influence the funding commitments a country receives as well as its likelihood of being elected to the board. The analysis also controls for two political variables that could have a significant impact on World Bank lending decisions or board election. The first is the 
Table 3. Summary Statistics for Members of the World Bank Board of Executive Directors, Alternates, and Nonmembers, 1961-2004

\begin{tabular}{|c|c|c|c|}
\hline Variable & $\begin{array}{l}\text { Number of } \\
\text { observations }\end{array}$ & Mean & Standard deviation \\
\hline \multicolumn{4}{|c|}{ International Bank for Reconstruction and Development } \\
\hline \multicolumn{4}{|l|}{ Statistics for board members } \\
\hline Bank voting power ( $\%$ total) & 420 & 1.193 & 1.179 \\
\hline Per capita real GDP (1995 US\$) & 407 & 4751 & 4242 \\
\hline Population (thousands) & 429 & 187734 & 344052 \\
\hline Major war (>1000 deaths, dummy variable) & 429 & 0.091 & 0.288 \\
\hline Democracy (scale -1 to 1 ) & 413 & 0.123 & 7.386 \\
\hline IBRD commitments (1996 US\$) & 429 & 387.3 & 637.4 \\
\hline \multicolumn{4}{|l|}{ Statistics for alternate board members } \\
\hline Bank voting power (\% total) & 489 & 0.438 & 0.411 \\
\hline Per capita real GDP (1995 US\$) & 420 & 5613 & 5302 \\
\hline Population (thousands) & 447 & 31693 & 40091 \\
\hline Major war (>1000 deaths, dummy variable) & 489 & 0.070 & 0.255 \\
\hline Democracy (scale -1 to 1 ) & 436 & -0.661 & 7.254 \\
\hline IBRD commitments (1996 US\$) & 489 & 165.9 & 367.9 \\
\hline \multicolumn{4}{|l|}{ Statistics for board nonmembers } \\
\hline Bank voting power (\% total) & 4,277 & 0.204 & 0.262 \\
\hline Per capita real GDP (1995 US\$) & 3,924 & 5021 & 6206 \\
\hline Population (thousands) & 4,533 & 13442 & 42881 \\
\hline Major war (>1000 deaths, dummy variable) & 4,727 & 0.069 & 0.253 \\
\hline Democracy (scale -1 to 1 ) & 3,607 & -1.335 & 7.411 \\
\hline IBRD commitments (1996 US\$) & 4,727 & 57.85 & 217.6 \\
\hline \multicolumn{4}{|l|}{ International Development Association } \\
\hline \multicolumn{4}{|l|}{ Statistics for board members } \\
\hline Bank voting power ( $\%$ total) & 391 & 1.154 & 1.152 \\
\hline Per capita real GDP (1995 US\$) & 406 & 4760 & 4244 \\
\hline Population (thousands) & 428 & 188133 & 344356 \\
\hline Major war (>1000 deaths, dummy variable) & 428 & 0.091 & 0.288 \\
\hline Democracy (scale -1 to 1 ) & 412 & 0.141 & 7.387 \\
\hline IBRD commitments (1996 US\$) & 428 & 172.3 & 435.9 \\
\hline \multicolumn{4}{|l|}{ Statistics for alternate board members } \\
\hline Bank voting power (\% total) & 427 & 0.528 & 0.511 \\
\hline Per capita real GDP (1995 US\$) & 419 & 5624 & 5303 \\
\hline Population (thousands) & 446 & 31762 & 40110 \\
\hline Major war (>1000 deaths, dummy variable) & 488 & 0.070 & 0.255 \\
\hline Democracy (scale -1 to 1 ) & 435 & -0.646 & 7.256 \\
\hline IBRD commitments (1996 US\$) & 488 & 49.37 & 146.75 \\
\hline \multicolumn{4}{|l|}{ Statistics for board nonmembers } \\
\hline Bank voting power (\% total) & 3,757 & 0.245 & 0.249 \\
\hline Per capita real GDP (1995 US\$) & 3,926 & 5019 & 6205 \\
\hline Population (thousands) & 4,535 & 13441 & 42872 \\
\hline Major war (>1000 deaths, dummy variable) & 4,729 & 0.069 & 0.253 \\
\hline Democracy (scale -1 to 1 ) & 3,609 & -1.338 & 7.410 \\
\hline IBRD commitments (1996 US\$) & 4,729 & 23.13 & 62.45 \\
\hline
\end{tabular}

Source: Authors' analysis based on data described in the text. 
occurrence of a war with at least 1,000 battle deaths in a given country-year, using data from the Department of Peace and Conflict Research at Uppsala University and the International Peace Research Institute in Oslo (Uppsala University and PRIO 2007). The second is the political climate in a country (whether its government can be characterized as a democracy, autocracy, or something in between), based on the Polity 2 variable developed by the University of Maryland's Center for International Development and Conflict Management in its Polity IV data set (Marshall and Jaggers 2007). This variable, coded as a score from -10 (perfect autocracy) to +10 (perfect democracy), is referred to as the Democracy variable.

\section{Primary Fixed Effects Specification}

Even after controlling for the variables just described, there are other omitted effects that could bias estimates of the value of a seat on the Board of Executive Directors in World Bank funding commitments. Country and year fixed effects in the main specification are used to account for such bias. Trends in World Bank funding over time will be absorbed by the year fixed effects, while omitted variables that affect individual countries' average loan receipts will be absorbed by the country fixed effects. The primary logarithmic fixed effects regression, following Alesina and Dollar (2000) and Kuziemko and Werker (2006), is as follows:

$$
\begin{aligned}
\ln (\text { Loan commitments })_{i t}= & \beta_{0}+\beta_{1}(\text { Board member })_{i t} \\
& +\beta_{2}(\text { Bank Voting Power })_{i t}+\beta_{3}(\mathbf{X})_{i t}+\boldsymbol{\gamma}_{t}+\boldsymbol{\delta}_{i}+\varepsilon_{i t}
\end{aligned}
$$

where Loan commitments represents the amount of money committed by either the IBRD or the IDA to country $i$ in year $t$; Board member is a dummy variable for whether a country has a seat on the Board of Executive Directors; $X$ is a vector of time-varying World Bank, political, and economic controls for each country; $\boldsymbol{\gamma}$ is a vector of year fixed effects; and $\boldsymbol{\delta}$ is a vector of country fixed effects. Note that the half-year lag due to board terms beginning and ending in the middle of a calendar year (so that a country's last year serving as an executive director before leaving the board is actually only half a year) may bias estimates of $\beta_{1}$ downward. In another specification, the dummy variable for board membership is replaced by the scalar variable Board voting power.

\section{Event-Time Specification}

If countries use board membership to create awareness of their legitimate development needs, an increase in funding may not be entirely troubling. An event-time specification, similar to that used by Kuziemko and Werker (2006), helps rule out this and other alternative explanations. The event-time regression 
is as follows:

$$
\begin{aligned}
\ln (\text { Loan commitments })_{i t}= & \beta_{0}+\beta_{1}(T-3)_{i t}+\beta_{2}(T-2)_{i t}+\beta_{3}(T-1)_{i t} \\
& +\beta_{4}(\text { Board member })_{i t}+\beta_{5}(T+1)_{i t}+\beta_{6}(T+2)_{i t} \\
& +\beta_{2}(\text { Bank voting power })_{i t}+\beta_{3}(X)_{i t}+\gamma_{t}+\delta_{i}+\varepsilon_{i t}
\end{aligned}
$$

where $T-x$ is a dummy variable indicating that the year is $x$ full calendar years before a country begins its term on the Board of Executive Directors and $T+x$ is a dummy variable indicating that the year is $x$ full calendar years after the country has completed its term on the board. The time dummy variables are extended to $T-3$ years to account for the lag caused by executive director terms beginning in the middle of a calendar year. Because of this effect, $T-1$ includes half a year of board service. As with the primary fixed effects specification, this lag might bias the estimate of $\beta_{4}$ downward.

This specification enables identifying the effect of serving on the board by comparing a country's loan commitments during years of board membership with those in the years immediately before its term begins and the years immediately after its term ends. (It also enables identifying any lag structure between project conceptualization and board-approved commitments. An infrastructure project may require three or more years to iron out all the details, but other categories - like budget support_can be approved much faster.) A sharp increase in loan commitments during a country's term compared with the years immediately before and after the term would help to rule out alternative explanations for a positive association between board membership and Bank funding and lend credence to the pork-barrel hypothesis.

\section{RESULTS}

The analysis finds a striking contrast in the returns to board membership between the IDA and the IBRD.

\section{International Bank for Reconstruction and Development}

The results of the main specifications (regressions 1, 2, and 3) for IBRD commitments are presented in table 4. The first specification regresses the logarithm of IBRD funding commitments on the board membership dummy variable including country and year fixed effects but excluding control variables. The results show a statistically (at the 5 percent level) and quantitatively significant estimate of the coefficient of the board membership variable. The addition of control variables in regression 2 has a negligible effect on that estimate, which remains significant (at the 10 percent level). Board membership in a given year is associated with a 138 log-point, or roughly 300 percent, increase in World Bank loans to the country $\left(\mathrm{e}^{1.38}=2.97\right)$. While there are no significant 
TABle 4. Ordinary Least Squares Regressions of Logarithm of International Bank for Reconstruction and Development Commitments on Board Membership (1996 U.S. dollars)

\begin{tabular}{|c|c|c|c|c|}
\hline Variable & Regression (1) & Regression (2) & Regression (3) & Regression (4) \\
\hline Board member & $\begin{array}{l}1.464 \\
(1.99)^{* *}\end{array}$ & $\begin{array}{l}1.382 \\
(1.97)^{*}\end{array}$ & & $\begin{array}{l}1.509 \\
(1.84)^{*}\end{array}$ \\
\hline Board voting power & & & $\begin{array}{c}0.539 \\
(2.49)^{* * *}\end{array}$ & \\
\hline World Bank voting power & & $\begin{array}{r}0.967 \\
(0.88)\end{array}$ & $\begin{array}{c}0.781 \\
(0.71)\end{array}$ & $\begin{array}{c}0.93 \\
(0.83)\end{array}$ \\
\hline $\ln ($ per capita real GDP $)$ & & $\begin{array}{l}1.982 \\
(1.6)\end{array}$ & $\begin{array}{l}1.998 \\
(1.6)\end{array}$ & $\begin{array}{c}1.96 \\
(1.57)\end{array}$ \\
\hline $\ln$ (population) & & $\begin{array}{l}0.368 \\
(0.12)\end{array}$ & $\begin{array}{l}0.393 \\
(0.12)\end{array}$ & $\begin{array}{l}0.331 \\
(0.1)\end{array}$ \\
\hline Major war & & $\begin{array}{l}-1.881 \\
(2.51) * *\end{array}$ & $\begin{array}{l}-1.882 \\
(2.51) * *\end{array}$ & $\begin{array}{l}-1.915 \\
(2.55)^{* *}\end{array}$ \\
\hline Democracy & & $\begin{array}{c}-0.01 \\
(0.26)\end{array}$ & $\begin{array}{c}-0.011 \\
(0.27)\end{array}$ & $\begin{array}{r}-0.011 \\
(0.27)\end{array}$ \\
\hline Board entry -3 years & & & & $\begin{array}{r}-0.835 \\
(1.15)\end{array}$ \\
\hline Board entry -2 years & & & & $\begin{array}{c}0.503 \\
(0.65)\end{array}$ \\
\hline Board entry -1 year & & & & $\begin{array}{c}0.054 \\
(0.07)\end{array}$ \\
\hline Board exit +1 year & & & & $\begin{array}{c}-0.096 \\
(0.1)\end{array}$ \\
\hline Board exit +2 years & & & & $\begin{array}{r}0.912 \\
(1.02)\end{array}$ \\
\hline Number of observations & 5645 & 4061 & 4061 & 4061 \\
\hline Number of countries & 173 & 135 & 135 & 135 \\
\hline $\mathrm{R}$ squared & 0.04 & 0.08 & 0.08 & 0.08 \\
\hline
\end{tabular}

"Significant at the 10 percent level; " significant at the 5 percent level; **"significant at the 1 percent level.

Note: Numbers in parentheses are the absolute values of robust $t$-statistics. All regressions include country and year fixed effects; standard errors are clustered at the country level.

Source: Authors' analysis based on data described in the text.

coefficients on the per capita income, population, or democracy controls in any of the main IBRD specifications, the occurrence of a major war in a country has a statistically significant negative effect on World Bank loans in all these specifications. The positive coefficient on per capita income indicates that a higher volume of IBRD loans flows to the middle-income countries in the sample.

Specification 3 replaces the dummy variable for board membership with a scalar representing a country's voting power on the board. Countries not serving on the board receive a value of zero. The positive coefficient on board voting power, significant at the 5 percent level, indicates that a 1 percentage point increase in board voting power (measured as a percentage of the total 
amount of available voting power) is associated with a 71 percent increase in IBRD loans.

Specification 4, the event-time specification, adds dummy variables for the years immediately before and after board service. The coefficient on board membership remains essentially unchanged (it increases slightly) and remains statistically significant at the 10 percent level. None of the dummy variables is statistically significant or shows any clear pattern, suggesting that there is an increase in Bank loans to a country during years when the country is serving on the board but not before its entry onto the board or after its exit. If omitted characteristics such as changes in a country's reputation within the World Bank or changes in a country's development needs are influencing both a country's election to the Board of Executive Directors and its ability to attract Bank funding, a rise in funding would be expected not just during years of service but in the years before and after service as well. If countries use board membership as a platform to draw attention to their legitimate development needs, that increased awareness would not be expected to disappear after the country completes its board term. By helping rule out several alternative hypotheses, the event-time specification lends credence to the hypothesis that increases in IBRD loans are closely tied to an insider bonus for countries serving on the board.

Alternative Specifications. Regressions were also run with several alternative specifications (table 5). First, the dependent variable, the logarithm of IBRD commitments, is replaced with absolute commitment levels. The absolute regressions are included because there is no obvious ex ante reason to believe that loan bonuses work as a proportion of existing loans. Specification 1 shows that the board membership variable is significant at the 10 percent level, indicating an approximately $\$ 60$ million bonus from board membership. While the major war control variable ceases to be significant in this regression, a positive coefficient on per capita GDP, significant at the 10 percent level, suggests that wealthier developing countries may see larger Bank loans in a given year. Event-time specification 2, using absolute commitment values as the dependent variable, shows higher Bank loans only in years of board service and the year immediately before board service. (Since the analysis for the year immediate before board service includes the first half-year of board service due to the lag caused by the Bank's election schedule, as described in section II, this result also confirms the findings in the main specifications.)

Specifications 3 and 4 present the results of a logit model used to determine whether board membership can explain a country's receipt of World Bank loans in a given country-year. ${ }^{4}$ These results also show a positive coefficient on the board membership variable, suggesting a story on the extensive margin that

4. Tobit and Heckman models failed to converge with country and year fixed effects. The logit sample size is reduced since observations that never change board member status are dropped. 
TA BLE 5. Alternative Specifications: Ordinary Least Squares Regressions of International Bank for Reconstruction and Development Commitments on Board Membership (1996 U.S. dollars)

\begin{tabular}{|c|c|c|c|c|c|c|}
\hline Variable & Absolute (1) & Absolute (2) & Logit (3) & Logit (4) & $\log (5)$ & $\log (6)$ \\
\hline Board member & $\begin{array}{l}59.758 \\
(1.90)^{*}\end{array}$ & $\begin{array}{l}72.256 \\
(2.08) * *\end{array}$ & $\begin{array}{l}0.513 \\
(1.64)\end{array}$ & $\begin{array}{r}0.575 \\
(1.55)\end{array}$ & $\begin{array}{l}1.835 \\
(2.38)^{* *}\end{array}$ & $\begin{array}{l}1.739 \\
(2.02) * *\end{array}$ \\
\hline Alternate board member & & & & & $\begin{array}{l}1.953 \\
(3.12) * * *\end{array}$ & $\begin{array}{l}2.468 \\
(3.33) * * *\end{array}$ \\
\hline Bank voting power & $\begin{array}{l}62.687 \\
(1.2)\end{array}$ & $\begin{array}{c}55.917 \\
(1.06)\end{array}$ & $\begin{array}{c}0.521 \\
(0.88)\end{array}$ & $\begin{array}{r}0.515 \\
(0.86)\end{array}$ & $\begin{array}{c}0.995 \\
(0.95)\end{array}$ & $\begin{array}{l}1.135 \\
(1.1)\end{array}$ \\
\hline $\ln ($ per capita real GDP) & $\begin{array}{r}113.717 \\
(1.73) *\end{array}$ & $\begin{array}{r}111.489 \\
(1.67)^{*}\end{array}$ & $\begin{array}{c}1.017 \\
(1.91)^{*}\end{array}$ & $\begin{array}{c}1.008 \\
(1.89)^{*}\end{array}$ & $\begin{array}{l}1.867 \\
(1.5)\end{array}$ & $\begin{array}{l}1.768 \\
(1.41)\end{array}$ \\
\hline $\ln$ (population) & $\begin{array}{c}-67.594 \\
(0.81)\end{array}$ & $\begin{array}{r}-68.569 \\
(0.82)\end{array}$ & $\begin{array}{r}-0.277 \\
(0.19)\end{array}$ & $\begin{array}{c}-0.292 \\
(0.2)\end{array}$ & $\begin{array}{c}0.561 \\
(0.18)\end{array}$ & $\begin{array}{c}0.582 \\
(0.19)\end{array}$ \\
\hline Major war & $\begin{array}{r}-34.029 \\
(1.34)\end{array}$ & $\begin{array}{r}-35.204 \\
(1.39)\end{array}$ & $\begin{array}{l}-1.06 \\
(2.89) * * *\end{array}$ & $\begin{array}{l}-1.093 \\
(3.01) * * *\end{array}$ & $\begin{array}{l}-1.825 \\
(2.46) *\end{array}$ & $\begin{array}{l}-1.86 \\
(2.53) *\end{array}$ \\
\hline Political climate & $\begin{array}{r}-1.734 \\
(1.13)\end{array}$ & $\begin{array}{r}-1.839 \\
(1.24)\end{array}$ & $\begin{array}{r}0.005 \\
(0.22)\end{array}$ & $\begin{array}{r}0.005 \\
(0.22)\end{array}$ & $\begin{array}{c}-0.008 \\
(0.21)\end{array}$ & $\begin{array}{r}-0.005 \\
(0.14)\end{array}$ \\
\hline Executive director entry -3 years & & $\begin{array}{r}-7.76 \\
(0.29)\end{array}$ & & $\begin{array}{c}-0.418 \\
(1.42)\end{array}$ & & $\begin{array}{l}-1.676 \\
(2.09) * *\end{array}$ \\
\hline Executive director entry -2 years & & $\begin{array}{c}6.309 \\
(0.22)\end{array}$ & & $\begin{array}{c}0.253 \\
(0.81)\end{array}$ & & $\begin{array}{c}-0.24 \\
(0.3)\end{array}$ \\
\hline Executive director entry -1 year & & $\begin{array}{l}74.235 \\
(1.75) *\end{array}$ & & $\begin{array}{c}-0.121 \\
(0.39)\end{array}$ & & $\begin{array}{c}-0.654 \\
(0.82)\end{array}$ \\
\hline Executive director exit +1 year & & $\begin{array}{r}-12.589 \\
(0.52)\end{array}$ & & $\begin{array}{c}-0.09 \\
(0.23)\end{array}$ & & $\begin{array}{c}-0.038 \\
(0.04)\end{array}$ \\
\hline Executive director exit +2 years & & $\begin{array}{c}40.952 \\
(0.92)\end{array}$ & & $\begin{array}{c}0.491 \\
(1.28)\end{array}$ & & $\begin{array}{c}1.033 \\
(1.15)\end{array}$ \\
\hline Alternate entry -3 years & & & & & & $\begin{array}{c}0.366 \\
(0.55)\end{array}$ \\
\hline Alternate entry -2 years & & & & & & $\begin{array}{l}1.763 \\
(2.74)^{* * * *}\end{array}$ \\
\hline
\end{tabular}


TABLE 5. Continued

\begin{tabular}{|c|c|c|c|c|c|c|}
\hline Variable & Absolute (1) & Absolute (2) & Logit (3) & Logit (4) & $\log (5)$ & $\log (6)$ \\
\hline Alternate entry - 1 year & & & & & & $\begin{array}{l}2.38 \\
(3.17)^{* * *}\end{array}$ \\
\hline Alternate exit +1 year & & & & & & $\begin{array}{c}0.483 \\
(0.65)\end{array}$ \\
\hline Alternate exit +2 years & & & & & & $\begin{array}{l}0.398 \\
(0.5)\end{array}$ \\
\hline Number of observations & 4,061 & 4,061 & 3,148 & 3,148 & 4,061 & 4,061 \\
\hline Number of countries & 135 & 135 & & & 135 & 135 \\
\hline $\mathrm{R}$ squared & 0.1 & 0.1 & & & 0.08 & 0.09 \\
\hline
\end{tabular}

"Significant at the 10 percent level; * significant at the 5 percent level; **significant at the 1 percent level.

Note: Numbers in parentheses are the absolute values of robust $t$-statistics. All regressions include country and year fixed effects; standard errors are clustered at the country level.

Source: Authors' analysis based on data described in the text. 
is similar to that found in the logarithmic and absolute specifications, although the coefficients are not statistically significant at conventional levels.

Finally, the IBRD analysis is extended in specification 5 by adding dummy variables representing alternate board membership to specification 1 . While the coefficient estimate for board membership does not change much, the coefficient on the alternate board membership variable is also significant and similar in magnitude. A $t$-test comparing the coefficients on board membership and alternate board membership shows no significant difference. The remaining variable coefficients, including that of the significant major war variable, show little change from the main specifications without alternate membership. Since alternate board members may participate in board meetings but may vote only when the appointing executive director is absent, the similar positive and statistically significant effect on alternate and full board members suggests that the loan increases resulting from board membership may stem not just from formal power, but also from the informal norms governing the board, its relationship with Bank staff, and its exercise of power.

An analysis of board minutes available on the World Bank's website (minutes from the first IBRD and IDA board meetings of each month since April 2005) suggests that there may be little difference in practice in the voting power of directors and alternates. The limited sample of minutes from these 58 meetings (results available on request) shows that an average of 10.4 executive directors were present in their voting capacity and that an average of 13.6 of the 24 voting seats were occupied by alternate directors voting in place of their executive directors. Only 3.8 alternates, on average, were present as nonvoting attendees. While this limited sample seems to confirm the finding that alternate board membership may have an effect similar to that of full board membership, the findings on the influence of alternate directors are not as robust, as demonstrated in the event-time specification in column 6 of table 5 .

Robustness Checks. A series of robustness checks (reported in table S2 of the online supplemental appendix) explore potential limitations of the main analysis, using various techniques to further validate the findings. To correct for any potential case selection bias, all countries in the dataset that have never served on the board were dropped from the analysis. To ensure that the particularities of the logarithmic specification (when zero commitment values are not uncommon) are not driving the results, the regressions were rerun after raising all zero commitment values to 12.5 , a value just below the lowest nonzero logarithmic commitment value in the data. The findings remain, with the coefficients (mechanically) reduced. To ensure that no other particularities of the panel data format are driving the result, the board member variable was replaced with a placebo-board membership 10 years before-and no positive coefficient was found on the placebo variable.

For each group of countries in the World Bank whose interests are represented by a single executive director, there are different expectations about 
who will represent the group. For most groups, member countries-at least the larger ones-take turns on the board. But for a handful of groups, such as the one that includes India, one country always maintains the seat. As an additional robustness check, groups that do not allow meaningful rotation are dropped from the analysis. The patterns remain the same. Another way to conceive of the empirical specification is to take advantage of this group data by adding group-year fixed effects. This specification essentially compares countries that serve on the board with countries in their group that are not on the board. Even with the large reduction in degrees of freedom, the same patterns remain, though the coefficient on the absolute level of commitments loses more than half its magnitude. Finally, the results are robust to dropping countries with income below $\$ 800$ per capita, as such countries are more likely to borrow through the IDA (available on request).

\section{International Development Agency}

The results of the main specifications for the IDA are presented in table 6 . In stark contrast to the findings for the IBRD, the regression of IDA funding on board membership with country fixed effects but without control variables shows no significant association between the two variables (column 1). The main specifications again fail to yield a statistically significant coefficient estimates on the board membership variable (columns 2-4). As with the main IBRD specifications, the only control variable that is significant is that for the occurrence of a major war. Mirroring the IBRD case, countries experiencing a major ongoing war can expect a very large decrease in IDA funding. The coefficient on per capita income, in contrast to the IBRD specification, is negative, indicating that IDA grants and loans flow to the poorer countries in the sample. The alternate specifications using absolute commitment levels as the dependent variable (columns 5 and 6) similarly fail to find a significant link between board membership and funding. ${ }^{5}$ (While answering a different question, these results complement those of Andersen and others (2006), who find that IDA allocation is correlated with U.S. strategic interest.)

The vast difference in results for the IBRD and the IDA raises interesting questions. Why would two institutions, similarly structured, exhibit such different behavior for the association between board membership and funding? One plausible explanation is that the difference stems from their different missions. The IDA's exclusive focus on the poorest, neediest countries might well alter

5. Since the IDA targets low-income countries, it may be prudent, as one referee suggested, to limit the sample to countries with especially low income per capita. The analysis revealed that the IDA regularly awarded projects to countries with GDP per capita upwards of \$4,000 (in 1996 dollars). The specifications in table 6 were rerun, alternately limiting the sample to countries with incomes of $\$ 8,000$ and $\$ 800$ per capita; the lack of significance for the board member variable remained (results available on request). The sample limited to $\$ 800$, due partly to its smaller size, was particularly noisy and not robust to modifications. However, the coefficients on board member were closer in magnitude to those in the IBRD sample. 
TA B Le 6. Ordinary Least Squares Regressions of International Development Association Commitments on Board Membership (1996 U.S. dollars)

\begin{tabular}{|c|c|c|c|c|c|c|}
\hline Variable & $\log (1)$ & $\log (2)$ & $\log (3)$ & $\log (4)$ & $\begin{array}{l}\text { Absolute } \\
\text { (5) }\end{array}$ & $\begin{array}{l}\text { Absolute } \\
\text { (6) }\end{array}$ \\
\hline Board member & $\begin{array}{r}-0.007 \\
(0.01)\end{array}$ & $\begin{array}{c}0.328 \\
(0.47)\end{array}$ & & $\begin{array}{c}0.408 \\
(0.55)\end{array}$ & $\begin{array}{c}9.03 \\
(0.5)\end{array}$ & $\begin{array}{c}8.585 \\
(0.61)\end{array}$ \\
\hline Board voting power & & & $\begin{array}{c}0.042 \\
(0.24)\end{array}$ & & & \\
\hline World Bank voting power & & $\begin{array}{r}-0.672 \\
(0.51)\end{array}$ & $\begin{array}{r}-0.641 \\
(0.49)\end{array}$ & $\begin{array}{c}-0.71 \\
(0.54)\end{array}$ & $\begin{array}{r}-32.368 \\
(0.86)\end{array}$ & $\begin{array}{r}-32.268 \\
(0.86)\end{array}$ \\
\hline $\ln ($ per capita real GDP) & & $\begin{array}{c}-1.531 \\
(1.12)\end{array}$ & $\begin{array}{c}-1.516 \\
(1.1)\end{array}$ & $\begin{array}{c}-1.542 \\
(1.12)\end{array}$ & $\begin{array}{r}-13.077 \\
(0.62)\end{array}$ & $\begin{array}{r}-12.811 \\
(0.61)\end{array}$ \\
\hline $\ln$ (population) & & $\begin{array}{r}-0.09 \\
(0.02)\end{array}$ & $\begin{array}{c}-0.064 \\
(0.02)\end{array}$ & $\begin{array}{r}-0.088 \\
(0.02)\end{array}$ & $\begin{array}{c}25.799 \\
(0.92)\end{array}$ & $\begin{array}{c}25.775 \\
(0.92)\end{array}$ \\
\hline Major war & & $\begin{array}{l}-2.309 \\
(3.19)^{* * *}\end{array}$ & $\begin{array}{l}-2.311 \\
(3.19)^{* * *}\end{array}$ & $\begin{array}{l}-2.292 \\
(3.16)^{* * * *}\end{array}$ & $\begin{array}{r}-38.292 \\
(1.70)^{*}\end{array}$ & $\begin{array}{r}-38.376 \\
(1.69) *\end{array}$ \\
\hline Democracy & & $\begin{array}{c}0.013 \\
(0.38)\end{array}$ & $\begin{array}{l}0.014 \\
(0.4)\end{array}$ & $\begin{array}{c}0.011 \\
(0.33)\end{array}$ & $\begin{array}{c}-0.248 \\
(0.63)\end{array}$ & $\begin{array}{r}-0.24 \\
(0.61)\end{array}$ \\
\hline Board entry -3 years & & & & $\begin{array}{c}0.433 \\
(0.59)\end{array}$ & & $\begin{array}{r}-10.77 \\
(1.11)\end{array}$ \\
\hline Board entry -2 years & & & & $\begin{array}{l}1.068 \\
(1.47)\end{array}$ & & $\begin{array}{c}8.04 \\
(0.83)\end{array}$ \\
\hline Board entry -1 year & & & & $\begin{array}{c}0.683 \\
(0.95)\end{array}$ & & $\begin{array}{c}-3.415 \\
(0.49)\end{array}$ \\
\hline Board exit +1 year & & & & $\begin{array}{r}-0.452 \\
(0.64)\end{array}$ & & $\begin{array}{r}-3.009 \\
(0.58)\end{array}$ \\
\hline Board exit +2 years & & & & $\begin{array}{r}-0.802 \\
(1.54)\end{array}$ & & $\begin{array}{r}-4.285 \\
(0.63)\end{array}$ \\
\hline Number of observations & 5,624 & 3,619 & 3,619 & 3,619 & 3,619 & 3,619 \\
\hline Number of countries & 173 & 122 & 122 & 122 & 122 & 122 \\
\hline R squared & 0.05 & 0.04 & 0.04 & 0.05 & 0.05 & 0.05 \\
\hline
\end{tabular}

"Significant at the 10 percent level; * significant at the 5 percent level; ***significant at the 1 percent level.

Note: Numbers in parentheses are the absolute values of robust $t$-statistics. All regressions include country and year fixed effects; standard errors are clustered at the country level.

Source: Authors' analysis based on data described in the text.

the dynamics of board politics and decisionmaking, reducing the effect of its institutional structure on outcomes. A more specific explanation centers on the strong role of easily observable factors such as per capita income and region in dictating IDA allocations since its early years. In fact, the IDA has used specific formulas for funding allocation since 1977. A third explanation, suggested by World Bank staff, is that the IDA has an additional institutional structure of approval, effectively weakening the power of the board. Evidence for India has found that fiscal transfers became much less politically determined when they were transferred to an independent agency (Khemani 2007). Testing these hypotheses is beyond the scope of this article, as this norm has been present with the organization since its founding, even though the IDA did not adopt 
specific formulas until 1977. That said, the correlation between IDA board membership and grants and loans-weak at all times-is weaker before 1977, suggesting that the norm rather than the formula is the driving factor (results available on request).

\section{Differential Treatment}

To follow up on the finding that board membership does lead to higher IBRD commitments, do certain characteristics allow countries to exploit board membership better than other countries do? The primary fixed effects specification is rerun with various interaction effects:

$$
\begin{aligned}
\ln (\text { Loan commitments })_{i t}= & \beta_{0}+\beta_{1}(\text { Board member })_{i t}+\beta_{1}(\text { Board member } x \eta)_{i t} \\
& +\beta_{2}(\text { Bank voting power })_{i t}+\beta_{3}(X)_{i t}+\gamma_{t}+\delta_{i}+\varepsilon_{i t}
\end{aligned}
$$

where $\eta$ is the variable being interacted with the dummy variable Board member.

The first interaction term examines whether a country's per capita GDP influences the benefit it derives from board membership. It is possible that economically stronger developing countries may command more respect or influence, making them more able to cash in on insider status.

Second, the interaction between board membership and democracy determines whether political climate (a country's degree of autocracy or democracy) has an effect on a country's ability to convert board membership into funding. For example, the board may be biased against more autocratic governments, limiting their ability to benefit from an insider position.

Third, the analysis explores whether the effect of board membership on World Bank funding is significantly different in the years before and after the cold war by interacting board membership with a dummy variable indicating whether the year is after 1990. The end of the cold war altered the balance of power in the international system and, consequently, might have influenced the operations of international institutions in a noteworthy manner.

Fourth, board membership is interacted with a dummy variable indicating whether a country has served on the board for more than 14 years-approximately a third of the time covered by the data set. Countries that have served longer might have more experience and command more respect on the board, enabling them to take greater advantage of their board membership. On the other hand, countries that frequently serve on the board may be less eager to exploit the opportunity or may see the returns spread out over multiple board terms.

Fifth, board membership is interacted with board voting power in a regression that pools the dummy and the scalar variables for board 
membership and tests whether countries representing powerful groups achieve larger gains from board service.

Sixth, board membership is interacted with a scaled measure of board voting power labeled Effective voting power. Since developed countries do not receive World Bank loans, board voting power is multiplied by the ratio of total votes to developing country votes. A developing country that shares its board seats with developed countries (which are not clamoring for loans) should have a larger effective vote than a developing country that shares its board seats with other developing countries.

And finally, board membership is interacted with the total annual loan volume of the IBRD. Since IBRD loans are ostensibly set at market rates, the benefit of securing a loan may be limited during quiet years in international finance. (Of course, because sovereign debt markets were very poorly developed before the 1980s, and because World Bank loans stretch well beyond the political horizon of most politicians, the IBRD has remained an attractive place to borrow.) The total annual volume of IBRD loans serves as a proxy for the value of a World Bank loan to a potential borrower since commercial loans are harder, if not impossible, to find in years of crisis, making the otherwise "market" rates of the IBRD relatively more attractive. ${ }^{6}$ This specification tests the hypothesis that when the value of a Bank loan is high, directors with a seat on the board will be more likely to exercise their influence to direct a loan to their home country.

The results of these various interaction effects are reported in table 7 . Specification 1 shows a positive but not statistically significant estimate of the coefficient of the interaction between per capita GDP and board membership. The interaction between board membership and democracy in specification 2 yields a negative coefficient, but one that is also not statistically significant.

Specification 3 shows that the financial bonus from board membership is substantially higher after 1990. There could be several explanations for this finding: the opening of international political space to developing countries following the depoliticization of strategic aid, the influence of the new states emerging from the formerly Communist countries, or changes in the rules and norms at the World Bank. The estimate on the interaction term in specification 4 suggests that countries that have served on the board for more than 14 years see higher returns to board membership, though this coefficient estimate is not quite statistically significant.

The results for specification 5 display a positive but not statistically significant effect, indicating that it is hard to determine whether countries with greater board voting power convert their board membership into higher IBRD commitments. Specification 6 shows that statistically significant additional

6. Alternate indicators are unavailable because of the poorly developed sovereign bond market. Emerging market bond yields are available only for a subset of countries and beginning only in the 1980s. 
Table 7. Differential Treatment of Board Membership: Ordinary Least Squares Regressions of International Bank for Reconstruction and Development Commitments on Board Membership (1996 U.S. dollars)

\begin{tabular}{|c|c|c|c|c|c|c|c|}
\hline Dependent variable and interaction terms & GDP (1) & $\begin{array}{c}\text { Democracy } \\
(2)\end{array}$ & $\begin{array}{l}\text { Post-1990 } \\
\text { (3) }\end{array}$ & $\begin{array}{c}>14 \text { years } \\
\text { on board }(4)\end{array}$ & $\begin{array}{c}\text { Board voting } \\
\text { power }(5)\end{array}$ & $\begin{array}{l}\text { Effective } \\
\text { vote }^{\text {a }}(6)\end{array}$ & $\begin{array}{c}\text { Total IBRD } \\
\text { loans (7) }\end{array}$ \\
\hline Board member & $\begin{array}{c}-2.688 \\
(0.53)\end{array}$ & $\begin{array}{l}1.369 \\
(2.04) * *\end{array}$ & $\begin{array}{c}0.326 \\
(0.37)\end{array}$ & $\begin{array}{c}0.539 \\
(0.76)\end{array}$ & $\begin{array}{c}-1.917 \\
(0.98)\end{array}$ & $\begin{array}{c}-0.521 \\
(0.56)\end{array}$ & $\begin{array}{c}-2.640 \\
(1.35)\end{array}$ \\
\hline Board voting power ${ }^{b}$ & & & & & $\begin{array}{c}0.485 \\
(1.43)\end{array}$ & & \\
\hline Effective voting power ${ }^{\mathrm{a}, \mathrm{b}}$ & & & & & & $\begin{array}{l}0.047 \\
(0.4)\end{array}$ & \\
\hline Bank voting power & $\begin{array}{c}0.877 \\
(0.81)\end{array}$ & $\begin{array}{c}0.776 \\
(0.72)\end{array}$ & $\begin{array}{c}0.96 \\
(0.84)\end{array}$ & $\begin{array}{c}0.724 \\
(0.72)\end{array}$ & $\begin{array}{c}0.499 \\
(0.43)\end{array}$ & $\begin{array}{l}0.863 \\
(0.8)\end{array}$ & $\begin{array}{c}0.803 \\
(0.76)\end{array}$ \\
\hline $\ln ($ per capita real GDP) & $\begin{array}{c}1.932 \\
(1.59)\end{array}$ & $\begin{array}{l}1.999 \\
(1.62)\end{array}$ & $\begin{array}{c}1.76 \\
(1.51)\end{array}$ & $\begin{array}{c}2.001 \\
(1.62)\end{array}$ & $\begin{array}{c}1.282 \\
(1.04)\end{array}$ & $\begin{array}{c}1.22 \\
(0.98)\end{array}$ & $\begin{array}{c}1.088 \\
(0.90)\end{array}$ \\
\hline $\ln$ (population) & $\begin{array}{r}0.345 \\
(0.11)\end{array}$ & $\begin{array}{c}0.268 \\
(0.08)\end{array}$ & $\begin{array}{c}0.484 \\
(0.15)\end{array}$ & $\begin{array}{l}0.307 \\
(0.1)\end{array}$ & $\begin{array}{r}0.717 \\
(0.22)\end{array}$ & $\begin{array}{c}0.466 \\
(0.14)\end{array}$ & $\begin{array}{c}0.487 \\
(0.15)\end{array}$ \\
\hline Major war & $\begin{array}{l}-1.894 \\
(2.54) * *\end{array}$ & $\begin{array}{l}-1.866 \\
(2.47) * * *\end{array}$ & $\begin{array}{l}-2.024 \\
(2.75) * * *\end{array}$ & $\begin{array}{l}-1.903 \\
(2.55) *\end{array}$ & $\begin{array}{l}-1.69 \\
(2.33) * *\end{array}$ & $\begin{array}{l}-1.697 \\
(2.31)^{* *}\end{array}$ & $\begin{array}{c}-1.743 \\
(2.37)\end{array}$ \\
\hline Democracy & $\begin{array}{c}-0.009 \\
(0.23)\end{array}$ & $\begin{array}{c}-0.002 \\
(0.05)\end{array}$ & $\begin{array}{c}-0.008 \\
(0.21)\end{array}$ & $\begin{array}{r}-0.007 \\
(0.19)\end{array}$ & $\begin{array}{l}0 \\
(0.01)\end{array}$ & $\begin{array}{c}0.001 \\
(0.02)\end{array}$ & $\begin{array}{c}0.002 \\
(0.06)\end{array}$ \\
\hline Board member* $\ln ($ per capita real GDP) & $\begin{array}{c}0.504 \\
(0.78)\end{array}$ & & & & & & \\
\hline Board member*Democracy & & -0.114 & & & & & \\
\hline
\end{tabular}


Board member*Post-1990

Board member*( $>14$ years on board $)$

Board member*Board voting power

Board member*Effective voting power ${ }^{\mathrm{b}}$

Board member*Total IBRD loans

Number of observations

Number of countries

R squared

$(1.12)$

$$
\begin{gathered}
3.126 \\
(2.53)^{* *}
\end{gathered}
$$

\begin{tabular}{|c|c|c|c|c|c|c|}
\hline & & & & $\begin{array}{c}0.943 \\
(1.52)\end{array}$ & $\begin{array}{c}0.406 \\
(2.28)^{* * *}\end{array}$ & \\
\hline & & & & & & $\begin{array}{l}0.000256 \\
(1.94)^{* *}\end{array}$ \\
\hline 4,061 & 4,061 & 4,061 & 4,061 & 3,673 & 3,673 & 3,673 \\
\hline 135 & 135 & 135 & 135 & 134 & 134 & 134 \\
\hline 0.08 & 0.08 & 0.08 & 0.08 & 0.06 & 0.06 & 0.06 \\
\hline
\end{tabular}

$$
(1.45)
$$

"Significant at the 10 percent level; * significant at the 5 percent level; ** significant at the 1 percent level.

Note: Numbers in parentheses are the absolute values of robust $t$-statistics. All regressions include country and year fixed effects; standard errors are clustered at the country level.

a. Effective vote is Board voting power multiplied by the total votes per board member divided by the total developing country votes.

b. These values are assigned to all countries in the group regardless of their board status.

Source: Authors' analysis based on data described in the text. 
leverage is gained from representing the votes of developed countries that are not interested in extra loans for themselves. This suggests that developing countries sharing a seat with donor countries are better able to use their board seat to draw more loans.

Finally, specification 7 indicates that when total loan volumes are higher, board members direct even more loans to their home countries. (Since the regression included year dummy variables, this means that board members fared even better than usual, relative to nonmembers.) This result is statistically significant at the 10 percent level. Recall that total loan volume is used as an indicator of the value of a Bank loan. The rise in benefits to board membership in proportion to the value of a loan serves as a causality check on the porkbarrel hypothesis.

Consistent with the lack of significant findings in all the IDA specifications described in section IV, the differential treatment of board membership also fails to reveal any statistically significant effect for the IDA board (reported in table S3 in the online supplemental appendix).

\section{Conclusions and Implications}

The findings of this analysis point to and quantify (for the World Bank) a dilemma of global governance: when the number of decisionmakers is limited, countries that are not part of the debate may be short-changed in the distribution of benefits.

A seat on the IBRD's Board of Executive Directors is important not just for intangible reasons such as international prestige but also for the large increase in loan commitments that executive directors bring to their home countries. A developing country serving on the board can expect, on average, a more than doubling of its normal funding levels or, in absolute terms, a nearly $\$ 60$ million bonus. Furthermore, board membership, rather than omitted trends or alternative explanations, appears to drive much of this striking effect.

The evidence also suggests that the returns to board membership are higher for board members in the post-Cold War era, for developing countries whose voting power on the board also represents that of developed countries, and for countries fortunate enough to be on the board when IBRD loans are most sought after. Yet the story is not simply one of rules and abuse. Comparison of the influence of executive directors and their alternates shows no significant difference in additional loans received, even though the executive director wields much more formal power. If it were simply a matter of formal institutional power, alternates should not have done as well as executive directors in bringing home loans.

Instead, this analysis suggests that the reward to board membership may stem more from boardroom norms and informal rules and the relationship between board members and World Bank staff than simply from voting rights. In the U.S. Congress, pork-barrel politics and logrolling are tolerated as a cost 
of the political process. But such behavior on international appropriations committees deserves more skepticism, because power there is determined by a much less structured international system. If board membership were egalitarian, with all countries having the same opportunity to serve on a regular basis, the findings reported here might not be troubling. However, a majority of World Bank member countries never or rarely get a seat at the table. An additional warning: research in corporate finance has shown that firms with overcompensated directors and weak shareholder rights underperform (Brick, Palmon, and Wald 2006; Gompers, Ishii, and Metrick 2003).

While the analysis finds strong results for the IBRD, it finds no significant association between board membership and IDA funding. This stark contrast between two institutions with similar decisionmaking structures suggests that this institutional design may not always be problematic. The difference may lie in the IDA's exclusive focus on the world's poorest and neediest countries or its strong norm of using external information to drive credit allocations, suggesting that governance challenges can be overcome through a less discretionary mandate.

\section{REFERENCES}

Alesina, Alberto, and David Dollar. 2000. "Who Gives Aid to Whom and Why?" Journal of Economic Growth 5 (1): 33-63.

Andersen, T.B., H. Hansen, and T. Markussen. 2006. "U.S. Politics and World Bank IDA Lending." Journal of Development Studies 42 (5): 772-94.

Bebchuk, L., and J. Fried. 2004. Pay without Performance: The Unfulfilled Promise of Executive Compensation. Cambridge, Mass.: Harvard University Press.

Brick, I.E., O. Palmon, and J.K. Wald. 2006. "CEO Compensation, Director Compensation, and Firm Performance: Evidence of Cronyism?” Journal of Corporate Finance 12 (3): 403-23.

Carsey, T.M., and B. Rundquist. 1999. "The Reciprocal Relationship between State Defense Interest and Committee Representation in Congress." Public Choice 99 (3-4): 455-63.

Ferejohn, J. 1974. Pork Barrel Politics: Rivers and Harbors Legislation, 1947-1968. Palo Alto, Calif.: Stanford University Press.

Gompers, P.A., J.L. Ishii, and A. Metrick. 2003. “Corporate Governance and Equity Prices.” Quarterly Journal of Economics 118 (1): 107-55.

Heston, A., R. Summers, and B. Aten. 2006. Penn World Table Version 6.2. University of Pennsylvania, Center for International Comparisons of Production, Income, and Prices, Philadelphia, Pa. Available at http://pwt.econ.upenn.edu.

IDA (International Development Association). 2004. "IDA's Performance-Based Allocation System: IDA Rating Disclosure and Fine-tuning the Governance Factor." International Development Agency, Washington, D.C. Available at http://siteresources.worldbank.org/IDA/Resources/PBAFINAL.pdf.

Kapur, D., J.P. Lewis, and R. Webb. 1997. The World Bank: Its First Half Century. Washington, D.C.: Brookings Institution Press.

Khemani, S. 2007. "Does Delegation of Fiscal Policy to an Independent Agency Make a Difference? Evidence from Intergovernmental Transfers in India." Journal of Development Economics 82 (2): 464-84. 
Kilby, C. 2009. "The Political Economy of Conditionality: An Empirical Analysis of World Bank Loan Disbursements." Journal of Development Economics 89 (1): 51-61.

Kuziemko, I., and E. Werker 2006. "How Much Is a Seat on the Security Council Worth? Foreign Aid and Bribery at the United Nations.” Journal of Political Economy 114 (5): 905-30.

Malone, D.M. 2000. "Eyes on the Prize: The Quest for Nonpermanent Seats on the U.N. Security Council." Global Governance 6 (1): 3-24.

Marshall, M., and K. Jaggers. 2007. Polity IV Project Data Set. University of Maryland, Center for International Development and Conflict Management, College Park, Md. Available at www.cidcm. umd.edu/polity.

Momani, B. 2007. “Another Seat at the Board: Russia's IMF Executive Director.” International Journal 62 (4): 916-39.

Ray, B.A. 1981. "Military Committee Membership in the House of Representatives and the Allocation of Defense Department Outlays." The Western Political Quarterly 34 (2): 222-34.

Rundquist, B., J. Lee, and J. Rhee. 1996. “The Distributive Politics of Cold War Defense Spending: Some State-Level Evidence.” Legislative Studies Quarterly 21 (2): 265-81.

Rundquist, B.S., and T.M. Carsey. 2002. Congress and Defense Spending: The Distributive Politics of Military Procurement. Norman, Okla.: University of Oklahoma Press.

Uppsala University and PRIO (Peace Research Institute Oslo). 2007. UCDP Database. Uppsala Conflict Data Program. Uppsala University, Department of Peace and Conflict Research, Uppsala, Sweden, and Peace Research Institute Oslo. Available at www.ucdp.uu.se/database.

Woods, N. 2001. "Making the IMF and World Bank More Accountable." International Affairs 77 (1): 83-100.

World Bank. 2007. Articles of Agreement. Washington, D.C.: World Bank. Available at http://go. worldbank.org/BAEZH92NH0.

—. 2010. "Boards of Governors." http://go.worldbank.org/YM7PNV31I0.

. Various years. Annual Report. Washington, D.C.: World Bank. Available at http://go. worldbank.org/VLWFADE5O0. 